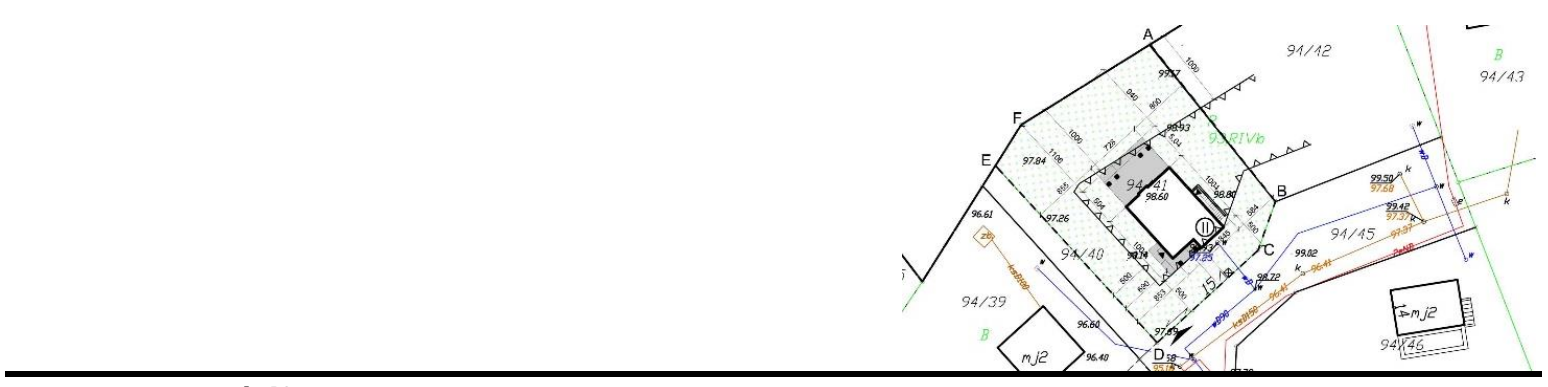

DOI: 10.21005/pif.2020.44.B-08

\title{
RELATIONS BETWEEN ARCHITECT AND INVESTOR INFLUENCING SPATIAL FORMING
}

\author{
RELACJE ARCHITEKTA I INWESTORA \\ WPŁYWAJĄCE NA KSZTAŁTOWANIE PRZESTRZENI
}

\author{
Łukasz Rosiak \\ Mgr inż. arch. \\ Author's Orcid number: 0000-0001-8823-0430 \\ Uniwersytet Technologiczno-Przyrodniczy w Bydgoszczy \\ Wydział Budownictwa, Architektury i Inżynierii Środowiska \\ Katedra Architektury i Urbanistyki
}

\begin{abstract}
The article presents comparison of two visions of shaping the immediate surroundings. The first concept is created by an architect directly involved in the creation of the project, guarding the spatial order and taking into account the requirements of legal acts. On the other hand the investor builds the second vision as the entity initiating the entire construction process and determining its character. He is responsible for the analysis of the project and budget rationalization, and his predispositions affect the decision-making and the final shape of the architectural and construction project.
\end{abstract}

Key words: Stakeholders, participatory design, space.

\section{STRESZCZENIE}

Celem artykułu jest próba porównania dwóch wizji kształtowania najbliższego otoczenia. Pierwszą z koncepcji kreuje architekt bezpośrednio zaangażowany w tworzenie projektu, stojący na straży ładu przestrzennego i uwzględniający wymogi aktów prawnych. Natomiast drugą wizję buduje inwestor, jako podmiot inicjujący cały proces budowlany i decydujący o jego charakterze. To on jest odpowiedzialny za analizę przedsięwzięcia i racjonalizację budżetu, a jego predyspozycje wpływają na decyzyjność i ostateczny kształt projektu architektoniczno-budowlanego.

Słowa kluczowe: Interesariusze, projektowanie partycypacyjne, przestrzeń. 


\section{INTRODUCTION}

The catalog of phenomena integrating the issues of the contact between art and technology, focusing in the field of architecture and urban planning, is expanding freely. Currently, architecture is not only a creative work which is the art of shaping space, an element of delineating a technical design or expanding the list of visionary buildings - symbols that become icons of the times in which they are created. In the era of digitization and the development of technical thought, architecture is a phenomenon that includes modern forms of design, i.e. visualization, augmented reality or social participation in architectural design, which has been functioning for a relatively short time in the history of architecture. The contemporary world flexibly adjusts to new conditions and phenomena it has to face. Such flexible shaping of various forms in building the identity of places blurs the boundaries of difference, thus leading to the universality of the design phenomenon. Another aspect of this universalism, existing on a macro scale, is the emergence of a global trend that speaks in favor of a design method involving people not professionally associated with a group of designers (laymen), known as participatory design. On the other hand, in the micro scale it refers to showing certain differences in educating generations of groups of local communities. In other words, the inhabitants of, for example, Zakopane in Poland and the inhabitants of the Apennine Peninsula have different views on the subject of the environment. In addition to the undeniable facts that we are dealing with different latitudes, differently operating the sun, different geological and soil conditions or a different regional culture, the issue of mentality, temperament and upbringing of the community is also important.

In an increasing number of countries, trends of more social architectural design begin to appear at a different pace. Architects in Poland also try to catch up with designers from abroad and introduce the client, as a co-participant, to an advanced, decision-making design process. In the case of such cooperation, the investor has a feeling that the designed building and the solutions adopted in it are part of the democratic authorship (Rosiak Ł. 2014, p. 284-293), and not the authoritarian vision of the designer - thus identifying himself with the resulting design.

The architect is obliged to keep the arrangements written in the files deciding on the development of a given area. It is in particular a local spatial development plan or a decision on development conditions. ... the reach of public consultations while preparing draft local plans is negligible. This is due to several reasons: low awareness and knowledge of citizens about spatial planning, lack of development of information and communication means with the society, lack of interest of municipal authorities in the broad participation of the society in the creation of local law. All the more so, as far as possible, at least the investor should participate in the architectural design, but recognizing the knowledge of the architect (Czekiel-Świtalska E. 2012, p. 325-338).

The presence of stakeholder groups in the process described above is indispensable. Space is a common good. Each person, having a specific affiliation in social life, occupies a part of this whole. That is why there are so many dependencies in the processes of spatial interference. At the same time, the social roles of an individual are a determinant, they are a marker of decisions made, often supported by the experience gained due to their social position.

The classification of space players can be done in several ways. One of them is the division into positive and negative players, depending on the usefulness of their role or the social undertaking they undertake. Another possibility is categorization according to the social role and a different goal in relation to a specific space, where examples of players are: designers, investors, government officials or people living in a neighboring plot. For some, the priority is to implement the life project, for others to provide shelter over the head, for state officials to fulfill all formalities necessary to obtain an administrative decision, while the neighbors focus on the safety of their own property, so that the newly built development does not introduce restrictions and nuisance to their household.

In this work, the author, on the basis of small cubature objects and observed phenomena during the design process with individual investors, will try to explain the differences in the way of looking at the subject of space between the designer and the investor and present the translation of decision-making factors into the shape of this space. For this purpose, he will use two examples with which he had contact in the second half of 2019. 
This article is to have the analytical features of two different attitudes of the investor towards the architect. The aim of this work is to address the continuing problem of differences in perception of the environment. It is to talk about what is important for the designer and what is important for the client. For the analysis of the above investor's attitudes the observational method was used. The collected results of the observation were interpreted as phenomena affecting the space.

\section{RELATIONSHIP ARCHITECT AND INVESTOR}

The emergence of new ventures is a series of cause and effect relationships between different spatial players. The process of designing small cubature buildings is largely based on the cooperation between the architect and the investor. This relationship can bring both the expected positive and undesirable negative results. The positive aspect manifests itself in the form of the involvement of own resources in creating space in common participation. The designer's own resource is technical knowledge, experience and the ability to solve problems with institutions agreeing the project. On the other hand, the investor has the means at his disposal which, when implemented on the market, are an element that drives the economy. However, a lack of understanding of each party in the design process, resulting from communication difficulties, can lead to a failed design.

The architect-investor relationship is always extremely complicated from the very beginning of cooperation. The reason for this complexity is believed to be the difficulty in precise communication between both of the spatial players. Architecture as an artistic and technical field of study shapes the student into a person who uses a language that is not very accessible to reception. The architect is socially misunderstood by using professional, complicated vocabulary from his own field. Failure to understand this may lead to incorrect design assumptions. Therefore, it becomes extremely important to establish an understanding on the basic conceptual level from the very beginning and look for methods to illustrate the fundamental elements of the project that will eliminate unwanted negative results of cooperation.

\section{Example 1:}

The author in August 2019. established cooperation with Investor $X^{1}$. He was a man aged 35-39, with a higher technical education (IT engineer, own business), whose intention was to build a single-family residential building in Kobylarnia (near Bydgoszcz, Kujawsko-Pomorskie Voivodeship). This area has a local spatial development plan, the provisions of which show:

1) intended use of the area - single-family housing development,

2) the applicable parameters and indicators of building development and land development:

a) height of buildings: residential - up to $9.5 \mathrm{~m}$,

b) the minimum width of the front elevation - $10 \mathrm{~m}$,

c) roof geometry: on residential buildings - implementation of high or medium-high roofs,

d) maximum building area $-30 \%$ of the plot area,

e) minimum area of biologically active land $-60 \%$ of the plot area.

Impassable line of buildings - $6 \mathrm{~m}$ from the front of the plot.

The first contact of both parties was unofficial, the intention to build a single-family house was communicated by Investor X. At the same time, the author of the article informed that he has the appropriate qualifications to carry out such a project. The next meeting was aimed at clarifying the Investor's expectations and defining mutual conditions for further cooperation. During it, Investor $\mathrm{X}$ presented the so-called design of a typical building, which surprised the designer. This procedure was the result of a misinterpretation of the architect's words, according to which the designer should have a ready basis for adapting the design to the Investor's expectations. The architect was responsible for the development of the area in accordance with the applicable Polish regulations and local arrangements of the local plan, and also pointed to the limitations resulting from the se-

\footnotetext{
${ }^{1}$ Ze względu na obowiązującą Ustawę o ochronie danych osobowych z dnia 10 maja 2018 r. Dz. U. 2018 poz. 1000 imiona i nazwiska Inwestorów zostały zmienione.
} 
lected land development. The investor, on the other hand, tried to influence the architect's decision by convincing about the rightness of his own solutions. Ultimately, his contribution to the shape of the surroundings was negligible and came down to the selection of one of the concepts prepared by the architect.

\section{Example 2:}

In November 2019. contact with Investor $\mathrm{Y}^{2}$ was initiated. The client is a man between $40-45$ years of age, with higher education (ICT engineer). Its intention was to build a summer house in Świekatowo (near Świecie, Kujawsko-Pomorskie Voivodeship). This area has a local spatial development plan, the provisions of which show:

1 ) it is possible to locate one single-story holiday building with an attic on individual plots; ground floor level max $1.20 \mathrm{~m}$ from the ground level; high, double or multi-pitch roofs with a slope of $45^{\circ}$ with a tolerance of $10^{\circ}$

2) if no building line is specified in the plan drawing or in the text, the minimum distance of the building development from the border of the neighboring plot should be $4.0 \mathrm{~m}$.

Impassable line of buildings - $5 \mathrm{~m}$ from the front of the plot.

The first meeting was official and boiled down to establishing specific directions for further mutual activities. The investor presented his own vision of the architecture of the planned facility, using visualizations of similar buildings posted on the Internet.

The architect's influence on the shape of the immediate surroundings is consistent with the development of the land development design in accordance with the applicable Polish regulations and local arrangements of the local plan. The investor, as in the first example, had a negligible contribution to the shape of the surroundings. He tried to persuade the architect to change the direction of the building's location. The investor cared about his own budget, tried to disturb the principles of shaping the uniform character of buildings and spatial order.

In both of the above cases, Investors were looking for a designer, not being aware of the role he plays in the process of building small cubature objects. They did not know at what stage they should turn to such a person and what they should have at their disposal before starting the talks. Although the goal for both Investors was to obtain a building permit and finally to build a residential building, their approach to the various stages of the project implementation differed significantly. These differences are summarized in Table 1.

Tab. 1. Comparison of Investor $X$ and Investor $Y$ - author: Łukasz Rosiak

\begin{tabular}{|c|c|c|c|}
\hline & & Investor X & Investor Y \\
\hline \multirow{8}{*}{ 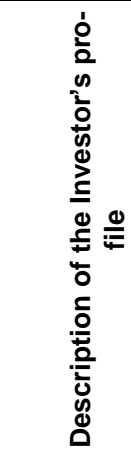 } & Sex & man & man \\
\hline & Age range & $35-39$ years old & $40-45$ years old \\
\hline & $\begin{array}{l}\text { Performed pro- } \\
\text { fession }\end{array}$ & $\begin{array}{l}\text { Information technology engineer } \\
\text { (higher education technical) }\end{array}$ & $\begin{array}{l}\text { ICT engineer (higher education tech- } \\
\text { nical) }\end{array}$ \\
\hline & Origin residence & single-family housing & multi-family housing development \\
\hline & & Investor X & Investor $Y$ \\
\hline & Current living & multi-family housing development & multi-family housing development \\
\hline & Individual goal & $\begin{array}{l}\text { single-family residential building pro- } \\
\text { ject adaptation }\end{array}$ & summer house - individual project \\
\hline & Overall goal & \multicolumn{2}{|c|}{ strives for a formal administrative decision to be able to build - a building permit } \\
\hline \multicolumn{2}{|c|}{$\begin{array}{l}\text { Investor's behawior at the pro- } \\
\text { gramming stage }\end{array}$} & $\begin{array}{l}\text { imposes his own design on the } \\
\text { architect, without consulting the } \\
\text { technical limitations of his own plot }\end{array}$ & $\begin{array}{l}\text { the architect is advised which of the } \\
\text { chosen solutions is the better proposition }\end{array}$ \\
\hline
\end{tabular}

\footnotetext{
${ }^{2}$ Ze względu na obowiązującą Ustawę o ochronie danych osobowych z dnia 10 maja 2018 r. Dz. U. 2018 poz. 1000 imiona i nazwiska Inwestorów zostały zmienione.
} 


\begin{tabular}{|l|c|c|}
\hline \multirow{1}{*}{$\begin{array}{l}\text { Investor's behawior at the de- } \\
\text { sign stage }\end{array}$} & $\begin{array}{c}\text { (purchase of a ready-made design) } \\
\text { he leaves no choice - he has already } \\
\text { made a choice }\end{array}$ & $\begin{array}{c}\text { is undecided on solutions / leaves } \\
\text { himself a choice of solutions }\end{array}$ \\
\hline & $\begin{array}{c}\text { questions the competences of the } \\
\text { architect, relying on the knowledge of } \\
\text { a person building houses with } 30 \\
\text { years of experience (negation of the } \\
\text { architect's knowledge) }\end{array}$ & $\begin{array}{c}\text { questions the competences of an } \\
\text { architect, using articles from construction } \\
\text { forums }\end{array}$ \\
\cline { 2 - 3 } & $\begin{array}{c}\text { changes his mind during the design } \\
\text { work, consulting with construction } \\
\text { foremen }\end{array}$ & $\begin{array}{c}\text { he does not change his mind, he } \\
\text { sticks to the initial arrangements }\end{array}$ \\
\cline { 2 - 3 } & $\begin{array}{c}\text { he only asks questions about the } \\
\text { doubts sown by the builders }\end{array}$ & $\begin{array}{c}\text { asks specific questions expecting } \\
\text { advice on technical issues }\end{array}$ \\
\cline { 2 - 3 } & $\begin{array}{c}\text { does not control the architect in the } \\
\text { course of design work }\end{array}$ & $\begin{array}{c}\text { controls the progress of work, imposes } \\
\text { the pace of implementation }\end{array}$ \\
\cline { 2 - 3 } & $\begin{array}{c}\text { he tries to help by starting his own } \\
\text { connections to speed up the proce- } \\
\text { dures }\end{array}$ & $\begin{array}{c}\text { it does not help, but checks whether } \\
\text { the architect has contacted the appropri- } \\
\text { ate office about it }\end{array}$ \\
\hline
\end{tabular}

The main difference between the attitudes of both Investors comes down to the course of cooperation at every stage of the project development process. From the designer's point of view, already at the stage of programming the facility, both positive and negative players can be recognized, although these are not behaviors with an unequivocally continued tendency throughout all stages of cooperation.

Investor $X$ shows negative features from the very beginning, imposing on the architect a ready concept of the building, inadequate to the local development plan. Then, a lack of trust in the designer's knowledge is demonstrated, relying on the opinion of people without appropriate competences and qualifications in doubtful matters, relying only on their opinion and experience. The lack of control of the progress of design works results from the lack of knowledge of procedures. However, in the final phase of the task, he tries to help by accelerating the actions of officials.

Investor $Y$ shows the features of a positive spatial player at the beginning of the cooperation. Having several solutions for objects, he uses the knowledge and experience of the architect, basing his future choice on his opinion. After determining the shape of the final concept, he explains the emerging doubts with the designer, while controlling his work. Unfortunately, this control is to impose the implementation of individual stages of the project at a pace inconsistent with the generally accepted course of this process, at the same time there is a lack of confidence in the correctness of these activities. Ultimately, the investor falls within the competences of the architect, contacting the office on formal issues related to obtaining a building permit.

The above-mentioned examples show how the Investor perceives the role of an architect in the design process. At the same time, it is an assessment of these people resulting from the current lack of need for contact on the plane of creating one's own space with a person professionally involved in it. The role of the designer is fundamentally different from the role of the investor in mutual cooperation, however, they have a common goal - to bring the project to the implementation stage. Table 2 presents different approaches.

Tab. 2. Characteristics of the architect and investor in the design process - author: Łukasz Rosiak

\begin{tabular}{|l|l|l|}
\hline & \multicolumn{1}{|c|}{ Architect } & \multicolumn{1}{|c|}{ Investor } \\
\hline Object programming & $\begin{array}{l}\text { Possibility to implement your own visions, } \\
\text { experience the act of creation }\end{array}$ & $\begin{array}{l}\text { Possibility to implement your own visions with } \\
\text { the help of a competent person }\end{array}$ \\
\hline $\begin{array}{l}\text { The context of the } \\
\text { object's surround- } \\
\text { ings }\end{array}$ & Caring for spatial order - example in Fig. 2 & $\begin{array}{l}\text { Not paying attention to the context of the } \\
\text { building surroundings - example in Fig. } 1\end{array}$ \\
\hline Functionality of & Taking care of the functionality of spatial & Incomplete awareness of the functionality of \\
\hline
\end{tabular}




\begin{tabular}{|l|l|l|}
\hline solutions & solutions & spatial solutions \\
\hline Technical solutions & $\begin{array}{l}\text { Taking care of the correctness of technical } \\
\text { solutions }\end{array}$ & No technical knowledge \\
\hline $\begin{array}{l}\text { Compliance with } \\
\text { regulations }\end{array}$ & $\begin{array}{l}\text { Ensuring that the project complies with the } \\
\text { regulations }\end{array}$ & No knowledge of the rules \\
\hline $\begin{array}{l}\text { Coordination of } \\
\text { industries }\end{array}$ & Ensuring inter-industry coordination & $\begin{array}{l}\text { Lack of awareness of the presence of industry } \\
\text { designers }\end{array}$ \\
\hline Purpose of activities & $\begin{array}{l}\text { Bringing the project to the implementation } \\
\text { stage }\end{array}$ & $\begin{array}{l}\text { Bringing the project to the implementation } \\
\text { stage }\end{array}$ \\
\hline
\end{tabular}

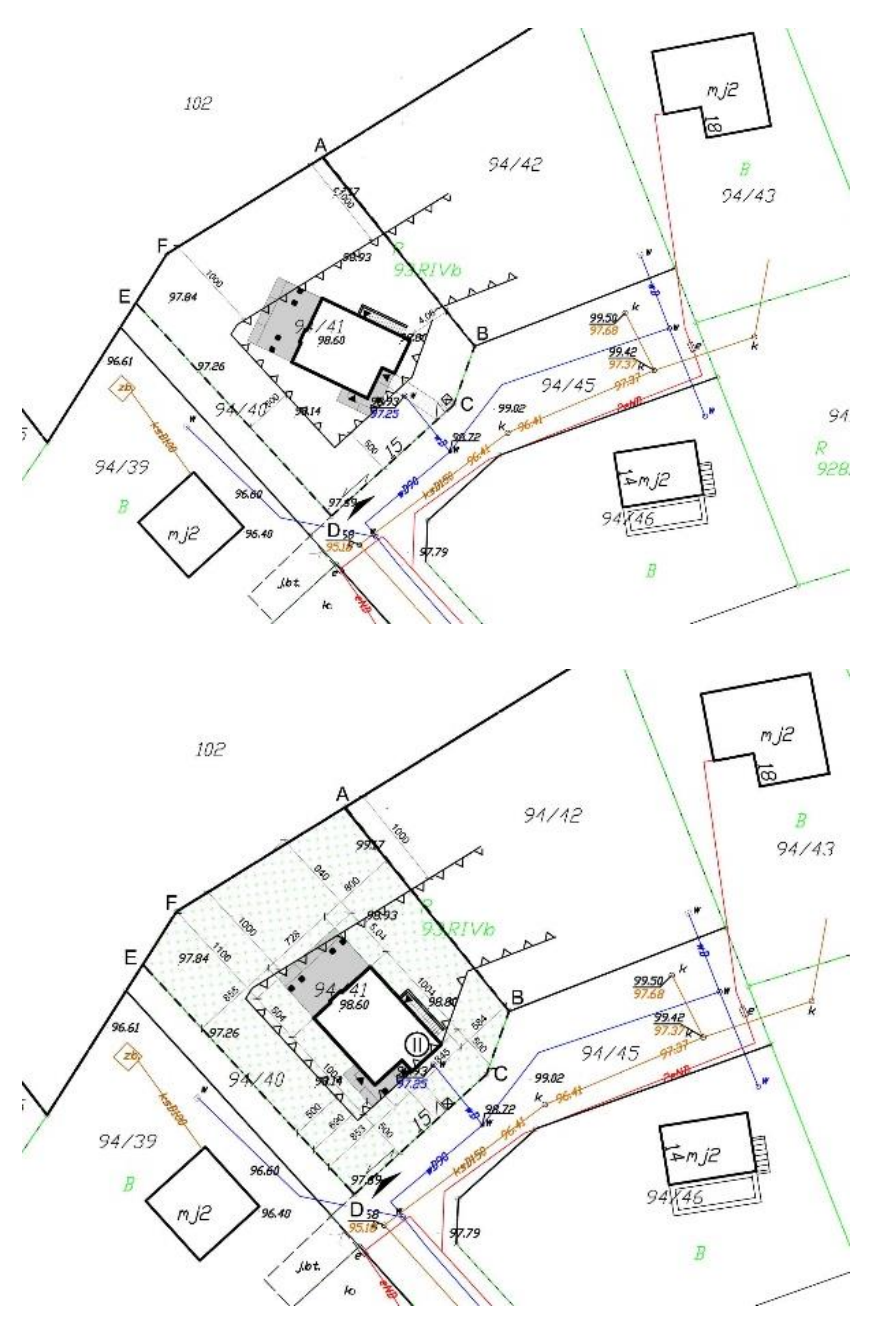

Fig. 1. Area development plan - investor concept - author: $Ł$. Rosiak

Ryc. 1. Plan zagospodarowania terenu - koncepcja Inwestora - autor: Ł. Rosiak

Fig. 2. Area development plan - architect concept - author: Ł. Rosiak

Ryc. 2. Plan zagospodarowania terenu - koncepcja architekta - autor: $Ł$. Rosiak

People who are not professionally related to design, do not know the roles of individual participants in the design process, as well as they do not respect certain dependencies resulting from the existing urban layout, spatial order, common principles of plan aesthetics or even understanding their own needs. Helpful for illustrating these elements is a flat drawing, which only defines the client's vision, which is not absolutely subordinated to the social voice (Barełkowski R. 2014, p. 25-46). Visual communication at this stage eliminates distortions or misunderstandings of the spoken message (Rosiak Ł. 2016, p. 237-147). Only a precise tool of the creator's work - a two-dimensional drawing - leads to the understanding of the overall thought of the designer, showing that the presented concept was the one desired and finally accepted by both sides. The architect, by shaping 
the space by not only placing the block, but also suggesting or even deciding where they are to be viewed, helps the investor to guide him on the right track (Pawłowska K. 2010, p. 17). At the same time, the above does not diminish the role of the user of the space, who has expert knowledge about it equal to, although different, from the architect's (Sanoff H. 1999, p. 56). The figures below, Fig. 1 and Fig. 2, showing two different concepts of the location of the building on the land development plan, are an ideal example illustrating the approach to understanding the subject of space by a layman and a professional.

A similar problem occurred with other solutions - the functional layout, the aesthetics of the facade drawing or issues arising from legal grounds. In order to understand the thought of the person creating his project, the investor needed confirmation in the drawing. This is what Augustyn Bańka writes: Architectural thinking, as different from technical or scientific thinking, consists in the simultaneous thinking in terms of strength, aesthetics and utility, the last two criteria seem to be even more important than the first. him. When designing the same building, an architect must consider the issues of comfort, sanitary and aesthetic, which means that all these aspects of the work determine the quality of life in line with the spirit of the epoch, with its predilections and aversions. The same author also believes that: Ordinary people also have practical knowledge, they can also be talented artists, but they are not professionals. What does it mean? Well, their knowledge is individual, private, not universal and idiosyncratic knowledge. Professionalism requires multidimensionality of competences, covering both legal, psychological, historical and methodological knowledge, as well as knowledge of how to solve problems in practice in various conditions: programming, research, experimenting, simulating. (Bańka A. 1997, p. 13 and 18).

\section{SUMMARY - NEGATIVES AND POSITIVES OF COOPERATION}

The conducted research suggests conclusions related to the analysis of both cases of the architect's cooperation with various Investors, combined with the overall subjective perception of the above-mentioned situations by the designer, it allows to assess which elements of this process are positive and which are negative, as presented in Table 3 .

Tab. 3. Summary of elements of the design process along with their assessment - author: Łukasz Rosiak

\begin{tabular}{|l|c|c|}
\hline Elements of the design process & Assessment of the Architect's position & Investor position assessment \\
\hline Spatial concepts & Positive & Positive \\
\hline Spatial order & Positive & Negative \\
\hline The functionality of solutions & Positive & Negative \\
\hline Unprofessional knowledge & Negative & Positive \\
\hline Professional knowledge & Positive & Negative \\
\hline Coordination Purpose of activities & Positive \\
\hline Provision of information & Negative (vocabulary) & Positive (vocabulary) \\
& / Positive (visualization) & / Negative (visualization) \\
\hline The final result & Positive & Positive \\
\hline
\end{tabular}

The interaction of both groups of stakeholders is complicated. Starting from the facility programming stage (wrong approach of the investor resulting from lack of contact with the topic) to the design stage (lack of trust, questioning competences, excessive unjustified control at various stages of the process), negative aspects in the Investor-Architect relationship are noticeable. The situation is not made easier by communication problems. The basis for this can be seen to a large degree in the complexity and complexity of the subject of the construction of buildings, issues completely alien to the average recipient. This leads to a social misunderstanding of designers. It is important to eliminate misunderstandings of the spoken message. Thanks to visual methods, using such creator's work tools as two-dimensional drawing, an architect can facilitate the understanding of his solutions based on his knowledge, technical guidelines or an inner sense of harmony. 
The very fact of cooperation is undoubtedly a positive aspect. For the investor, this cooperation leads to the expected result in the form of the achieved goal - the building design, allows him to increase the level of life satisfaction with the goal obtained and the completion of work on it. For a designer, it is another experience of creating something new. Designing is the process of defining problems and solving them, i.e. learning (Bańka A. 1997, p. 33). All clients should be approached individually, earned to gain their trust, because each of them represents a unique approach for the architect, resulting from personal character traits. The procedure to be followed in the design process, although it is repeatable, each time brings a previously unknown baggage of experience, due to the changeability of conditions, to other provisions of the local spatial development plan. Above all this, there is undoubtedly the aspect of participation in building the state's economy that is beneficial to both parties. The Investor's order ensures work for both architects and participants of the next stages of the investment related to the construction of the facility. The designer's contribution to building relationships with the client, passing on his professional knowledge and revealing the secrets of the sense of aesthetics and spatial order has an impact on shaping the awareness of the general public. New knowledge in the subject of conducting the design process gained by laymen has a positive effect on shaping their immediate environment in the future.

\section{RELACJE ARCHITEKTA I INWESTORA WPŁYWAJACCE NA KSZTALTOWANIE PRZESTRZENI}

\section{WPROWADZENIE}

Katalog zjawisk integrujących zagadnienia styku sztuki i techniki, skupiających się w dziedzinie architektury i urbanistyki, poszerza się w sposób nieskrępowany. Obecnie architektura to nie tylko praca twórcza będąca sztuką kształtowania przestrzeni, elementem wykreślania projektu technicznego czy poszerzaniem listy wizjonerskich budynków - symboli, stających się ikonami czasów, w których powstają. W dobie cyfryzacji i rozwoju myśli technicznej, architektura jest zjawiskiem obejmującym nowoczesne formy projektowania, tj. wizualizację, rozszerzoną rzeczywistość czy, funkcjonującą stosunkowo krótko w historii architektury, partycypację społeczną w projektowaniu urbanistycznym. Współczesny świat fleksybilnie dostosowuje się do nowych warunków i zjawisk z jakimi musi się zmierzyć. Takie elastyczne kształtowanie się zróżnicowanych form w budowaniu tożsamości miejsc zaciera granice odmienności, doprowadzając tym samym do uniwersalności zjawiska projektowania. Innym aspektem tegoż uniwersalizmu, istniejącym w skali makro, jest wykształcenie się ogólnoświatowego trendu, który przemawia za sposobem projektowania włączającym $w$ ten proces osoby niezwiązane zawodowo $z$ grupą projektantów nazywanego projektowaniem partycypacyjnym. Natomiast w skali mikro odnosi się ono do ukazania pewnych różnic w wychowaniu pokoleń grup lokalnych społeczności. Innymi słowy, różne spojrzenia na tematykę otoczenia mają mieszkańcy np.: Zakopanego w Polsce a ludność zamieszkująca tereny Półwyspu Apenińskiego. Oprócz niepodważalnych faktów, iż mamy do czynienia z różną szerokością geograficzną, inaczej operującym słońcem, innymi warunkami geologiczno-gruntowymi czy odmienną kulturą regionalną, istotną jest również kwestia mentalności, temperamentu czy wychowania społeczności.

W coraz większej ilości państw w różnym tempie zaczynają pojawiać się nurty bardziej społecznego projektowania architektonicznego. Architekci w Polsce również próbują doścignąć projektantów z zagranicy i wprowadzają klienta, jako współuczestnika, w zaawansowany, decyzyjny proces projektowy. W przypadku takiej współpracy inwestor ma poczucie, że projektowany budynek, i przyjęte w nim rozwiązania są częścią demokratycznego autorstwa (Rosiak Ł. 2014, s. 284-293), nie zaś autorytarnej wizji projektanta - utożsamia się w ten sposób z powstałym projektem.

Architekt jest zobligowany do zachowania ustaleń zapisanych w aktach decydujących o zagospodarowaniu danego terenu. Jest to w szczególności miejscowy plan zagospodarowania przestrzen- 
nego lub decyzja o warunkach zabudowy. [...] Zasięg konsultacji społecznych przy sporządzaniu projektów miejscowych planów jest znikomy. Wynika to z kilku przyczyn: małej świadomości i wiedzy obywateli o planowaniu przestrzennym, braku rozwijania środków informacji i komunikacji ze społeczeństwem, braku zainteresowania władz gmin w szerokim uczestnictwie społeczeństwa w tworzeniu prawa miejscowego. Tym bardziej na ile jest to możliwe przy projekcie architektonicznym powinien uczestniczyć przynajmniej inwestor, jednak uznając wiedzę architekta (CzekielŚwitalska E. 2012, s. 325-338).

Obecność grup interesariuszy w wyżej opisanym procesie jest elementem nieodzownym. Przestrzeń jest dobrem wspólnym. Każdy człowiek, mając określoną przynależność w życiu społecznym, zajmuje jakiś wycinek tej całości. Dlatego też w procesach ingerencji przestrzennych występuje tak wiele zależności. Jednocześnie role społeczne jednostki stanowią determinantę, są wyznacznikiem podejmowanych decyzji, niejednokrotnie podpartych zdobytym doświadczeniem z racji zajmowanej pozycji społecznej.

Klasyfikacji graczy przestrzennych można dokonać na kilka sposobów. Jeden z nich to podział na graczy pozytywnych i negatywnych, w zależności jaką przydatność niesie ze sobą ich rola czy podejmowane przedsięwzięcie społeczne. Kolejna możliwość stanowi kategoryzacja z uwagi na pełnioną rolę społeczną i odmienny cel względem określonej przestrzeni, gdzie przykładowymi graczami są: projektanci, inwestorzy, urzędnicy państwowi czy osoby zamieszkujące sąsiedzką działkę. Dla jednych priorytetem jest realizacja projektu życia, dla drugich zapewnienie schronienia nad głową, dla urzędników państwowych spełnienie wszelkich formalności niezbędnych do uzyskania decyzji administracyjnej, natomiast sąsiedzi skupiają się na bezpieczeństwie własnego mienia, by nowopowstająca zabudowa nie wprowadziła ograniczeń i uciążliwości w ich gospodarstwo domowe.

Autor w niniejszej pracy na podstawie małych obiektów kubaturowych i zaobserwowanych zjawisk podczas procesu projektowego $z$ indywidualnymi inwestorami, wyjaśnia różnice $w$ sposobie spojrzenia na tematykę przestrzeni pomiędzy projektantem a inwestorem oraz zaprezentować przekład czynników decyzyjnych na kształt tejże przestrzeni. Posłużą mu do tego celu dwa przykłady z jakimi miał styczność w drugiej połowie 2019 r.

Niniejszy artykuł ma mieć znamiona analityczne dwóch różnych postaw inwestora względem architekta. Praca ta ma poruszać niegasnący problem różnic w postrzeganiu otoczenia. Ma mówić o tym, co jest ważne dla projektanta, a co dla klienta.

Do analizy ww. postaw inwestora zastosowano metodę obserwacyjną. Zgromadzone wyniki obserwacji poddano interpretacji jako zjawiska oddziałujące na przestrzeń.

\section{RELACJA ARCHITEKT A INWESTOR}

Powstawanie nowych przedsięwzięć to szereg zależności przyczynowo-skutkowych pomiędzy różnymi graczami przestrzennymi. Proces projektowania obiektów kubaturowych w zasadniczej części opiera się na współpracy architekta z inwestorem oraz aktach prawnych decydujących o zagospodarowaniu danej nieruchomości. Relacja ta może przynieść zarówno oczekiwane rezultaty korzystne jak i niepożądane negatywne. Pozytywny aspekt przejawia się w formie zaangażowania zasobów własnych do tworzenia przestrzeni we wspólnym udziale. Zasobem własnym dla projektanta jest wiedza techniczna, doświadczenie, umiejętność rozwiazywania problemów z instytucjami uzgadniającymi projekt oraz wydającymi pozwolenie na budowę. Natomiast Inwestor dysponuje środkami, które przy wdrożeniu do obrotu są elementem napędzającym gospodarkę. Brak zrozumienia się każdej ze stron procesu projektowego, wynikający z trudności w komunikowaniu się, doprowadzić może jednak do projektu zakończonego niepowodzeniem.

Relacja architekt - inwestor jest zawsze niezwykle skomplikowana już od początku współpracy. Powodu tej zawiłości upatruje się w trudności w precyzyjnym komunikowaniu się obu z przestrzennych graczy. Architektura jako kierunek studiów jednocześnie artystyczny i techniczny, kształtuje adepta na człowieka posługującego się językiem niezbyt przystępnym w odbiorze. Architekt poprzez stosowanie fachowego, skomplikowanego słownictwa z własnej dziedziny jest nierozumiany społecznie. Niezrozumienie to może doprowadzić do przyjęcia błędnych założeń projektowych. 
Dlatego niezwykle istotne staje się aby, od samego początku nawiązać porozumienie na podstawowej płaszczyźnie pojęciowej i szukać metod zobrazowania fundamentalnych elementów projektu, które wyeliminują niepożądane negatywne rezultaty współpracy.

\section{Przykład 1}

Autor w sierpniu 2019r. nawiązał współpracę z Inwestorem X3. Był to mężczyzna w przedziale wiekowym 35-39 lat, z wykształceniem wyższym technicznym (inżynier informatyk, własna działalność gospodarcza), którego zamierzeniem była budowa budynku mieszkalnego jednorodzinnego w miejscowości Kobylarnia (okolice Bydgoszczy, woj. Kujawsko-pomorskie). Obszar ten posiada miejscowy plan zagospodarowania przestrzennego, z którego zapisów wynika:

1) przeznaczenie terenu - zabudowa mieszkaniowa jednorodzinna,

2) obowiązujące parametry i wskaźniki kształtowania zabudowy i zagospodarowania terenu:

a) wysokość budynków: mieszkalnych - do 9,5 m,

b) minimalna szerokość elewacji frontowej $-10 \mathrm{~m}$,

c) geometria dachów: na budynkach mieszkalnych - realizacja dachów wysokich lub średnio wysokich;

d) maksymalna powierzchnia zabudowy - $30 \%$ powierzchni działki,

e) minimalna powierzchnia terenu biologicznie czynnego $-60 \%$ powierzchni działki.

Nieprzekraczalna linia zabudowy $-6 \mathrm{~m}$ od frontu działki.

Pierwszy kontakt obu stron miał formę nieoficjalną, zakomunikowana przez Inwestora $X$ została chęć budowy domku jednorodzinnego. Jednocześnie autor artykułu poinformował, że posiada odpowiednie kwalifikacje aby wykonać taki projekt. Następne spotkanie miało na celu sprecyzować oczekiwania Inwestora i określić wzajemne warunki dalszej współpracy. Podczas niego Inwestor X zaprezentował zakupiony drogą on-line tzw. projekt budynku typowego, czym zaskoczył projektanta. Postępowanie to było wynikiem błędnej interpretacji słów architekta, wg której to projektant powinien mieć gotowy podkład do zaadaptowania projektu pod oczekiwania Inwestora. Architekt odpowiedzialny był za zagospodarowanie terenu zgodne z obowiązującymi polskimi przepisami, oraz lokalnymi ustaleniami miejscowego planu, a także wskazywał na ograniczenia wynikające z wybranego zagospodarowania terenu. Inwestor natomiast próbował wpłynąć na zmianę decyzji architekta przekonując o słuszności własnych rozwiązań. Finalnie jego wkład na kształt otoczenia był znikomy i sprowadził się do wyboru jednej z koncepcji, które przygotował architekt.

\section{Przykład 2}

W listopadzie 2019r. zainicjowany został kontakt z Inwestorem Y4. Klient to mężczyzna pomiędzy 40-45 lat, posiadający wyższe wykształcenie (inżynier teleinformatyk). Jego zamierzeniem była budowa budynku letniskowego w miejscowości Świekatowo (okolice Świecia, woj. Kujawskopomorskie). Obszar ten posiada miejscowy plan zagospodarowania przestrzennego, z którego zapisów wynika:

1) na poszczególnych działkach ustala się możliwość lokalizacji jednego budynku letniskowego parterowego z poddaszem użytkowym; poziom posadzki parteru max $1,20 \mathrm{~m}$ od poziomu terenu; dachy wysokie dwu- lub wielospadowe o nachyleniu $45^{\circ} z$ tolerancją $10^{\circ}$,

2) jeśli na rysunku planu bądź w tekście nie określono linii zabudowy minimalna odległość zabudowy od granicy działki sąsiedniej winna wynosić $4,0 \mathrm{~m}$.

Nieprzekraczalna linia zabudowy $-5 \mathrm{~m}$ od frontu działki.

Pierwsze ze spotkań miało charakter oficjalny i sprowadzało się do ustalenia konkretnych kierunków dalszych wzajemnych działań. Inwestor przedstawił własną wizję na architekturę planowanego obiektu, podpierając się wizualizacjami podobnych budynków zamieszczonych w Internecie.

\footnotetext{
${ }^{3}$ Ze względu na obowiązującą Ustawę o ochronie danych osobowych z dnia 10 maja 2018 r. Dz. U. 2018 poz. 1000 imiona i nazwiska Inwestorów zostały zmienione.

${ }^{4}$ Ze względu na obowiązującą Ustawę o ochronie danych osobowych z dnia 10 maja 2018 r. Dz. U. 2018 poz. 1000 imiona i nazwiska Inwestorów zostały zmienione.
} 
Wpływ architekta na kształt najbliższego otoczenia mieści się w wykonaniu projektu zagospodarowania terenu zgodnego z obowiązującymi polskimi przepisami, oraz lokalnymi ustaleniami miejscowego planu. Inwestor podobnie jak w pierwszym przykładzie miał znikomy wkład w kształt otoczenia. Próbował nakłonić architekta do zmiany kierunku lokalizacji budynku. Inwestor dbał o własny budżet, próbował zaburzać zasady kształtowania jednolitego charakteru zabudowy oraz ładu przestrzennego.

W obu powyższych przypadkach inwestorzy poszukiwali projektanta, nie mając świadomości jaką rolę pełni on w procesie budowy obiektów kubaturowych. Nie wiedzieli na jakim etapie powinni się zwrócić do takiej osoby i czym powinni dysponować przed rozpoczęciem rozmów. Pomimo, że dla obu inwestorów celem było uzyskanie pozwolenia na budowę i finalnie budowa budynku mieszkalnego, ich podejście do poszczególnych etapów realizacji projektu znacząco się różniło. Różnice te zestawione zostały w tabeli $\mathrm{nr} 1$.

Tab. 1. Porównanie podejścia do procesu projektowego Inwestora $X$ i Inwestora $Y$ - autor: Łukasz Rosiak

\begin{tabular}{|c|c|c|c|}
\hline & & Inwestor X & Inwestor Y \\
\hline \multirow{7}{*}{ 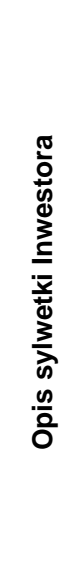 } & Płeć & mężczyzna & mężczyzna \\
\hline & Przedział wiekowy & 35-39 lat & $40-45$ lat \\
\hline & $\begin{array}{l}\text { Wykonywany } \\
\text { zawód }\end{array}$ & $\begin{array}{c}\text { inżynier informatyk } \\
\text { (wykształcenie wyższe } \\
\text { techniczne) }\end{array}$ & $\begin{array}{l}\text { inżynier teleinformatyk } \\
\text { (wykształcenie wyższe } \\
\text { techniczne) }\end{array}$ \\
\hline & $\begin{array}{l}\text { Pochodzenie } \\
\text { zamieszkania }\end{array}$ & zabudowa jednorodzinna & zabudowa mieszkaniowa wielorodzinna \\
\hline & $\begin{array}{l}\text { Obecne } \\
\text { zamieszkanie }\end{array}$ & zabudowa mieszkaniowa wielorodzinna & zabudowa mieszkaniowa wielorodzinna \\
\hline & Cel indywidualny & $\begin{array}{l}\text { budynek mieszkalny jednorodzinny - } \\
\text { adaptacja }\end{array}$ & budynek letniskowy - projekt indywidualny \\
\hline & Cel ogólny & \multicolumn{2}{|c|}{$\begin{array}{l}\text { dąży do formalnego uzyskania decyzji administracyjnej aby móc się budować - pozwo- } \\
\text { lenie na budowę }\end{array}$} \\
\hline \multirow{2}{*}{\multicolumn{2}{|c|}{$\begin{array}{l}\text { Zachowanie Inwestora na } \\
\text { etapie programowania }\end{array}$}} & $\begin{array}{l}\text { narzuca architektowi własny projekt, bez } \\
\text { konsultacji z nim technicznych ograniczeń } \\
\text { własnej działki (zakup gotowego projektu) }\end{array}$ & $\begin{array}{l}\text { radzi się architekta, które z wybranych } \\
\text { przez niego rozwiązań jest lepszą propo- } \\
\text { zycją }\end{array}$ \\
\hline & & $\begin{array}{l}\text { nie pozostawia sobie wyboru - już } \\
\text { dokonał wyboru }\end{array}$ & $\begin{array}{l}\text { jest niezdecydowany na rozwiązania / } \\
\text { pozostawia sobie wybór w kwestii rozwią- } \\
\text { zań }\end{array}$ \\
\hline \multirow{5}{*}{\multicolumn{2}{|c|}{$\begin{array}{l}\text { Zachowanie Inwestora na } \\
\text { etapie projektowania } \\
\text { Zachowanie Inwestora na } \\
\text { etapie projektowania }\end{array}$}} & $\begin{array}{l}\text { podważa kompetencje architekta, opiera- } \\
\text { jąc się na wiedzy osoby budującej domy z } \\
\text { 30-letnim doświadczeniem (negacja wie- } \\
\text { dzy architekta) }\end{array}$ & $\begin{array}{l}\text { podważa kompetencje architekta, pod- } \\
\text { pierając się artykułami z forów budowla- } \\
\text { nych }\end{array}$ \\
\hline & & $\begin{array}{l}\text { zmienia zdanie } w \text { trakcie prac projekto- } \\
\text { wych, radząc się majstrów budowlanych }\end{array}$ & $\begin{array}{l}\text { nie zmienia zdania, trzyma się początko- } \\
\text { wych ustaleń }\end{array}$ \\
\hline & & $\begin{array}{l}\text { zadaje pytania tylko w odniesieniu do } \\
\text { wątpliwości zasianych przez majstrów } \\
\text { budowlanych }\end{array}$ & $\begin{array}{l}\text { zadaje konkretne pytania oczekując } \\
\text { doradztwa w kwestiach technicznych }\end{array}$ \\
\hline & & $\begin{array}{l}\text { nie kontroluje architekta w postępach } \\
\text { prac projektowych }\end{array}$ & $\begin{array}{l}\text { kontroluje postęp prac, narzuca tempo } \\
\text { realizacji }\end{array}$ \\
\hline & & $\begin{array}{l}\text { próbuje pomóc uruchamiając własne } \\
\text { znajomości aby przyśpieszyć procedury }\end{array}$ & $\begin{array}{l}\text { nie pomaga, ale kontroluje czy architekt } \\
\text { kontaktował się w jego sprawie } z \text { właści- } \\
\text { wym urzędem }\end{array}$ \\
\hline
\end{tabular}

Zasadnicza różnica pomiędzy postawami obu Inwestorów sprowadza się do przebiegu współpracy na każdym etapie procesu powstawania projektu. Z punktu widzenia projektanta już na etapie programowania obiektu można rozpoznać zarówno pozytywnych jak i negatywnych graczy, aczkol- 
wiek nie są to zachowania z jednoznacznie kontynuowaną tendencją przez wszystkie fazy współdziałania.

Inwestor $X$ od początku wykazuje cechy negatywne, narzucając architektowi gotową koncepcję budynku, nieadekwatną do miejscowego planu zagospodarowania. Następnie wykazuje się brakiem zaufania do wiedzy projektanta, w kwestiach wątpliwych opierając się na zdaniu osób bez odpowiednich kompetencji i kwalifikacji, polegając jedynie na ich zdaniu i doświadczeniu. Brak kontroli postępu prac projektowych wynika z braku znajomości procedur. Jednak w końcowej fazie zadania stara się pomóc poprzez przyspieszenie działań urzędników.

Inwestor $Y$ na początku współpracy wykazuje cechy pozytywnego gracza przestrzennego. Dysponując kilkoma rozwiązaniami obiektów, korzysta z wiedzy i do-świadczenia architekta, swój przyszły wybór opierając na jego zdaniu. Po ustaleniu kształtu ostatecznej koncepcji, pojawiające się wątpliwości wyjaśnia z projektantem, kontrolując jednocześnie jego pracę. Niestety kontrola ta ma za zadanie narzucenie realizacji poszczególnych etapów powstawania projektu w tempie nieadekwatnym do ogólnie przyjętego przebiegu tego procesu, równocześnie pojawia się brak zaufania co do poprawności tych działań. Ostatecznie Inwestor wchodzi w kompetencje architekta, kontaktując się z urzędem w formalnych kwestiach dotyczących uzyskiwania pozwolenia na budowę.

Przytoczone przykłady obrazują w jaki sposób Inwestor postrzega rolę architekta w procesie projektowym. Jednocześnie jest to ocena tych osób wynikająca $z$ dotychczasowego braku potrzeby kontaktu na płaszczyźnie kreowania własnej przestrzeni wraz z osobą zawodowo się tym zajmującą. Rola projektanta zasadniczo różni się od roli inwestora podczas wzajemnej współpracy, jednakże przy-świeca im wspólny cel - doprowadzenie projektu do etapu realizacji. Odmienne podejścia przedstawione zostały w tabeli $\mathrm{nr} 2$.

Tab. 2. Charakterystyka architekta i inwestora w procesie projektowym - autor: Łukasz Rosiak

\begin{tabular}{|l|l|l|}
\hline \multicolumn{1}{|c|}{ Architekt } & \multicolumn{1}{c|}{ Inwestor } \\
\hline $\begin{array}{l}\text { Programowanie } \\
\text { obiektu }\end{array}$ & $\begin{array}{l}\text { Możliwość realizowania własnych wizji, do- } \\
\text { świadczenie aktu kreacji }\end{array}$ & $\begin{array}{l}\text { Możliwość realizowania własnych wizji z pomocą } \\
\text { kompetentnej osoby }\end{array}$ \\
\hline $\begin{array}{l}\text { Kontekst oto- } \\
\text { czenia obiektu }\end{array}$ & Dbanie o ład przestrzenny - przykład rys. 2 & $\begin{array}{l}\text { Niezwracanie uwagi na kontekst otoczenia budyn- } \\
\text { ku - przykład rys. 1 }\end{array}$ \\
\hline $\begin{array}{l}\text { Funkcjonalność } \\
\text { rozwiązań }\end{array}$ & $\begin{array}{l}\text { Dbanie o funkcjonalność rozwiązań prze- } \\
\text { strzennych }\end{array}$ & $\begin{array}{l}\text { Niepełna świadomość funkcjonalności rozwiązań } \\
\text { przestrzennych }\end{array}$ \\
\hline $\begin{array}{l}\text { Rozwiązania } \\
\text { techniczne }\end{array}$ & Dbanie o poprawność rozwiązań technicznych & Brak wiedzy technicznej \\
\hline $\begin{array}{l}\text { Zgodność z } \\
\text { przepisami }\end{array}$ & Dbanie o zgodność projektu z przepisami & Brak znajomości przepisów \\
\hline $\begin{array}{l}\text { Koordynacja } \\
\text { branż }\end{array}$ & Zapewnienie koordynacji międzybranżowej & $\begin{array}{l}\text { Brak świadomości występowania projektantów } \\
\text { branżowych }\end{array}$ \\
\hline Cel działań & Doprowadzenie projektu do etapu realizacji & Doprowadzenie projektu do etapu realizacji \\
\hline
\end{tabular}

U osób niezwiązanych zawodowo z projektowaniem powszechna jest nieznajomość ról poszczególnych uczestników procesu projektowego, a także niedostrzeganie przez nich pewnych zależności wynikających z istniejącego układu urbanistycznego, ładu przestrzennego, powszechnych zasad estetyki planu czy nawet zrozumienia własnych potrzeb. Pomocnym dla zobrazowania tych elementów staje się płaski rysunek, który to dopiero definiuje klientowi wizję, jaka nie jest bezwzględnie podporządkowana głosowi społecznemu (Barełkowski R. 2014, s. 25-46). Komunikacja wizualna na tym etapie niweluje zniekształcenia bądź niezrozumienia komunikatu słownego (Rosiak Ł. 2016, s. 237-147). Dopiero precyzyjne narzędzie pracy twórcy - dwuwymiarowy rysunek prowadzi do zrozumienia całościowej myśli projektanta, pokazując że zaprezentowana koncepcja była tą pożądaną i finalnie akceptowalną przez obie ze stron. Architekt, kształtując przestrzeń poprzez nie tylko ustawianie bryły, ale także sugerowanie lub wręcz decydowanie, skąd mają być oglądane, pomaga inwestorowi naprowadzić go na odpowiedni tor (Pawłowska K. 2010, s. 17). 
Powyższe jednocześnie nie ujmuje roli użytkownikowi przestrzeni, który posiada na jej temat wiedzę ekspercką równą, choć różniącą się, od wiedzy architekta (Sanoff H. 1999, s. 56). Poniżej prezentowane rysunki rys. 1 i rys. 2 przedstawiające dwie różne koncepcje umiejscowienia budynku na planie zagospodarowania terenu są idealnym przykładem obrazującym sposób podejścia do rozumienia tematyki przestrzeni przez laika i profesjonalistę.

Podobny problem występował z pozostałymi rozwiązaniami - układu funkcjonalnego, estetyki rysunku elewacyjnego czy kwestii wynikających z podstaw prawnych. Inwestor aby zrozumieć myśl osoby tworzącej jego projekt potrzebował potwierdzenia w rysunku. To tak jak pisze Augustyn Bańka: Myślenie architektoniczne, jako inne w stosunku do myślenia technicznego czy naukowego, polega z kolei na równoczesnym myśleniu kategoriami wytrzymałości, estetyki i użyteczności, przy czym dwa ostatnie kryteria wydają się nawet ważniejsze od pierwszego. Projektując ten sam budynek architekt musi rozważyć kwestie komfortu, sanitarne, estetyczne, czyli wszystkie te aspekty dzieła decydują o jakości życia zgodnego z duchem epoki, z jej predylekcjami i awersjami. Ten sam autor także uważa, że: Zwykli ludzie też posiadają wiedzę praktycznie użyteczną, mogą też być utalentowanymi artystami, tyle, że nie są profesjonalistami. Co to oznacza? Ano tyle, że ich wiedza jest wiedzą indywidualną, prywatną, nie uniwersalną $i$ idiosynkretyczną. Profesjonalizm wymaga wielowymiarowości kompetencji, obejmującej zarówno wiedzę prawną, psychologiczną, historyczną, metodologiczną, jak $i$ wiedze dotyczącą sposobu praktycznego rozwiązywania problemów w różnych warunkach: programowania, badania, eksperymentowania, symulowania. (Bańka A. 1997, s. 13 i 18).

\section{WNIOSKI - NEGATYWY I POZYTYWY WSPÓŁPRACY}

Z przeprowadzonych badań, wysuwają się wnioski związane $z$ analizą obu przypadków współpracy architekta z różnymi Inwestorami, w połączeniu z całościowym subiektywnym odbiorem przez projektanta powyższych sytuacji, pozwala ocenić, które elementy tego procesu są pozytywne, a które negatywne, co prezentuje tabela $\mathrm{nr} 3$.

Tab. 3. Podsumowanie elementów procesu projektowego wraz z ich oceną - autor: Łukasz Rosiak

\begin{tabular}{|l|c|c|}
\hline Elementy procesu projektowego & Ocena stanowiska Architekta & Ocena stanowiska Inwestora \\
\hline Koncepcje przestrzenne & Pozytywna & Pozytywna \\
\hline Ład przestrzenny & Pozytywna & Negatywna \\
\hline Funkcjonalność rozwiązań & Pozytywna & Pozytywna \\
\hline Wiedza nieprofesjonalna & Negatywna \\
\hline Wiedza profesjonalna & Pozytywna & Negatywna \\
\hline Projekty branżowe, koordynacja & Pozytywna & Negatywna \\
\hline Przekazywanie informacji & Negatywna (słownictwo) & Pozytywna (słownictwo) \\
& / Pozytywna (wizualizacja) & / Negatywna (wizualizacja) \\
\hline Cel działań - ostateczny efekt & Pozytywna & Pozytywna \\
\hline
\end{tabular}

Współdziałanie obu grup interesariuszy przebiega w skomplikowany sposób. Począwszy od etapu programowania obiektu po fazę projektowania, zauważalne są negatywne aspekty w relacji Inwestor-architekt. Dodatkowo sytuację pogłębia problem wzajemnej komunikacji. Podłoża tego można upatrywać w znacznym stopniu skomplikowania i złożoności tematu powstawania budynków, zagadnieniom zupełnie obcym przeciętnym odbiorcom. Prowadzi to do społecznego niezrozumienia projektantów. Ważne jest aby wyeliminować niezrozumienia komunikatu słownego. Dzięki sposobom wizualnym, stosując takie narzędzia pracy twórcy jak wizualizacje, architekt może ułatwić zrozumienie swoich rozwiązań opartych na posiadanej wiedzy, wytycznych technicznych czy wewnętrznemu poczuciu harmonii. 
Już sam fakt współdziałania bezsprzecznie należy uznać za aspekt pozytywny. Dla inwestora owa współpraca prowadzi do oczekiwanego rezultatu w postaci osiągniętego celu - projektu budynku, pozwala mu podnieść poziom życiowej satysfakcji z uzyskanego zamierzenia i zakończenia pracy nad nim. Dla projektanta to kolejne doświadczenie tworzenia czegoś nowego. Projektowanie to proces definiowania problemów i jego rozwiazywania czyli uczenia się (Bańka A. 1997, s. 33). Do wszystkich klientów należy podejść indywidualnie, zapracować na zdobycie ich zaufania, gdyż każdy z nich reprezentuje nowe dla architekta unikatowe podejście wynikające z osobistych cech charakteru. Procedura postępowania w procesie projektowania chociaż jest powtarzalna, to za każdym razem niesie wcześniej nieznany bagaż doświadczeń, ze względu na zmienność warunków, na inne zapisy miejscowego planu zagospodarowania przestrzennego. Ponad tym wszystkim pojawia się niewątpliwie korzystny dla obu stron aspekt udziału w kształtowaniu nowej przestrzeni. Zlecenie Inwestora zapewnia pracę zarówno architektom jak i uczestnikom kolejnych etapów inwestycji związanych z budową obiektu. Wkład projektanta w budowanie relacji ze zleceniodawcą, przekazywanie mu swojej fachowej wiedzy i odsłanianie tajników poczucia estetyki i ładu przestrzennego ma wpływ na kształtowanie świadomości części społeczeństwa. Nowa wiedza w temacie prowadzenia procesu projektowania zdobyta przez laików wpływa pozytywnie na kształtowanie przez nich najbliższego otoczenia w przyszłości.

\section{BIBLIOGRAPHY}

Bańka A., Architektura psychologicznej przestrzeni życia. Behawioralne podstawy projektowania, Poznań 1997.

Barełkowski R., Problemy implementacji projektowania partycypacyjnego w Polsce, [in:] Przestrzeń i Forma/Space \& Form no. 22, Polska Akademia Nauk Department in Gdańsk, Szczecin 2014, 25-46.

Czekiel-Świtalska E., PUBLIC CONSULTATION IN LOCAL PLANNING - SELECTED ISSUES/Konsultacje społeczne w planowaniu miejscowym - wybrane zagadnienia, [in:] Przestrzeń i Forma/Space \& Form no. 17, Polska Akademia Nauk Department in Gdańsk, Szczecin 2012, 325-338.

Rosiak Ł., Architektura i czynny udział społeczeństwa w decydowaniu o jakości przestrzeni życia, [in:] Habitaty: reaktywacja małych społeczności lokalnych, ed. Z. Bać, Wrocław 2014, 284-293.

Rosiak Ł., The significance of early stages in participatory design for social sustainability, w C. A. Brebbia, S. Hernandez (ed.) Eco-Architecture 2016, 6th International Conference on Harmonisation between Architecture and Nature, 13-15 July 2016, Wessex Institute of Technology, WIT Press, South-ampton \& Boston, 2016, p. 237-247.

Pawłowska K., Partnerstwo dla Środowiska, [w:] Pawłowska K. (red.), Zanim wybuchnie konflikt. Idea i metody partycypacji społecznej w ochronie krajobrazu i kształtowaniu przestrzeni, tom. A, Fundacja „Partnerstwo dla Środowiska", Kraków 2010.

Sanoff H., Integrowanie programowania ewaluacji i partycypacji w projektowaniu architektonicznym. Podstawy teorii Z, Poznań 1999.

Ustawa o ochronie danych osobowych z dnia 10 maja 2018 r. Dz. U. 2018 poz.

\section{AUTHOR'S NOTE}

Łukasz Rosiak - assistant lecturer at the University of Technology and Life Sciences in Bydgoszcz, architect. The scientific activity has two directions of interested-cations. The first is the participatory design. Another direction of interest is the contact of contemporary architecture and historic tissue.

\section{O AUTORZE}

Łukasz Rosiak - asystent, nauczyciel akademicki na Uniwersytecie Technologiczno-Przyrodniczym w Bydgoszczy, architekt. W działalności naukowej realizuje dwa kierunki zainteresowań: pierwszym jest projektowanie partycypacyjne, a drugim - styk architektury współczesnej z tkanką zabytkową.

Contact | Kontakt: lukasz.rosiak@utp.edu.pl 